Article

\title{
Stoic Theology: Revealing or Redundant?
}

\author{
Kai Whiting ${ }^{1, *}$ and Leonidas Konstantakos ${ }^{2}$ \\ 1 MARETEC_LARSyS, Instituto Superior Técnico, Universidade de Lisboa, Avenida Rovisco Pais 1, \\ 1049-001 Lisboa, Portugal \\ 2 School of International and Public Affairs, Florida International University, 11200 SW 8th St, Miami, \\ FL 33199, USA; lkons001@fiu.edu \\ * Correspondence: kaiwhiting@tecnico.ulisboa.pt or whitingke@yahoo.co.uk; \\ Tel.: +351-21-841-73-66 (ext. 1366)
}

Received: 12 February 2019; Accepted: 8 March 2019; Published: 14 March 2019

\begin{abstract}
With the notion of advancing a modern Stoic environmental ethical framework, we explore the philosophy's call to "living according to Nature", as derived from ancient Stoic theology. We do this by evaluating the orthodox (ancient) viewpoint and the contemporary criticisms levelled against it. We reflect on the atheistic interpretations of Stoicism and their associated call to "live according to the facts". We consider the limitations that this call has when applied to societal, and particularly non-human matters. We do not undertake this research with the aim of determining which view of Stoic theology is right or wrong. However, we contest one of the assumptions of the heterodox approach, namely that the Stoic worldview is incompatible with modern scientific thinking. Indeed, we demonstrate how Stoic theology, far from being outdated or irrelevant, is actually refreshingly contemporary in that it provides the tools, scope and urgency with which to deliver a far more considerate ethical framework for the 21st century. Finally, we suggest where Stoic theology can help practitioners to reframe and respond to environmental challenges, which we argue forms part of their cosmopolitan obligation to take care of themselves, others and the Earth as a whole.
\end{abstract}

Keywords: environmental ethics; climate change; nature; orthodox theology; pantheism; Stoicism; sustainable development; virtue ethics

\section{Introduction}

Stoicism is a Greco-Roman philosophy. Originally established by Zeno, out of Cynicism, and heavily influenced by Socrates and Plato, it was then further developed by Roman practitioners, most notably Seneca, Epictetus and Marcus Aurelius (Sellars 2014). Its ideas also influenced many key (non-Stoic) figures of the Enlightenment including Adam Smith and Francis Hutcheson. It continues to be of interest to modern scholars, most notably Julia Annas, Martha Nussbaum, A.A Long, Christopher Gill and Massimo Pigliucci.

More importantly, at least in the context of this present paper, is the continual development and re-interpretation of ancient Stoic principles within the Modern Stoicism movement. The latter, which emerged during the late 20th century, represents a growing community of lay members (and academics) committed to pursuing a "life worth living", through the day-to-day practice of the four Stoic virtues of courage, justice, self-control and wisdom (Gill 2014b; LeBon 2018). Indeed, in the last five years or so, there has been a proliferation of academic articles, blogs, trade and scholarly books, newspaper articles, conference attendees and informal affiliations to Stoic fellowships and social media groups. Those that practice Stoicism, or at least express an interest in it, come from diverse backgrounds. As of November 2018, there were 56 registered Stoic fellowship groups from all over the world, including Canada, France, Guatemala, Holland, Portugal, the UK and the US (Lopez 2018). 
Stoic Philosophy and Religious Belief

The modern Stoic movement incorporates a wide range of religious and spiritual inclinations. Among its contemporary practitioners, there are many that lean towards more atheistic or agnostic interpretations. There are pantheists and theists. The ancient Stoic texts also exhibit a range of attitudes to divinity. Marcus Aurelius sometimes seems to treat his ethical commitments as compatible with either "providence or atoms". We can look to Epictetus for more personified descriptions of the divine. The Stoic tradition in general "was a complex amalgam of pantheism and theism" (Long 2002, p. 147). All of them converged on one point: the logos.

In Stoicism, the logos is understood to be the perfectly rational benevolent Nature of the universe that connects everything in its causal nexus. The universe is considered the highest expression of rationality because of its order, structure and wholeness. It is paradigmatic in its benevolent/providential care for all component parts of the universe: the sea, air, rocks, plants and animals, including humans (Cicero, On the Nature of the Gods 2.83, 100-1, 122-30, Long and Sedley 1987, 54J).

The logos was, according to Diogenes Laertius, equally referred to by the Stoics as "god", "Zeus", "intellect" and "Fate". Other nouns ascribed to the term included "providence" and "Natural Law". It is important, so as to avoid confusion, to distinguish between the Stoic conception of natural law, which was itself Divine and the natural law as Thomas Aquinas understood it, where it was the creation of the Divine. Regardless of the exact word used, there was, among the ancient Stoics, an overarching agreement that the essence of the universe was a natural presence (a material soul, so to speak) actively permeating the whole and sustaining it:

[The Stoics say] that god is the mind of the world, and that the world is the body of god. (Lactantius, Divine Institutes VII.3 = SVF II. 1041)

A modern articulation of this worldview is expressed by renowned De Waal (2010) in his book The Age of Empathy: Nature's Lessons for a Kinder Society:

The way our bodies are influenced by surrounding bodies is one of the mysteries of human existence, but one that provides the glue that holds entire societies together. We occupy nodes within a tight network that connects all of us in both body and mind.

The logos pervades all elements of life. It is the essence of the universe which provides the foundation of humankind's rational nature and mandates what "excellent" behaviour consists of. It is, consequently, the literal reason everything exists and operates the way it does. The logos thus grounds ancient Stoic ethics into a framework that not only provides meaning but is "meaning". This understanding is exemplified by Cleanthes in Hymn to Zeus when he refers to the logos as the "common law of god" and the "one eternal rational principle" which, if rationally obeyed, leads to the "good life".

Incidentally, this is why the modern Becker (2017, p. xiii) wrote that Stoicism's logocentric foundation is not something that we should abandon casually. We, the authors, agree with Becker's sentiments. Indeed, before dismissing a core tenet in Stoic philosophy, one would be wise to first question whether hastily removing it, or underplaying its significance, might serve to hinder progress towards virtue. This remains the case even if prominent Stoic scholars such as Becker (2017); Irvine (2008); LeBon (2014) and Pigliucci $(2018,2017 b)$ argue that maintaining Stoic theology is untenable or unpalatable to modern sensibilities.

This paper does not pretend to be a comprehensive survey of all the ideas in the history of philosophy that might support sustainable action but instead a study of how Stoicism does so. At the same time, it is an in depth look at the way in which an updated Stoic theology based on the ancient cosmological framework might support a modern Stoic ethics. Consequently, in this paper, we explore the value of maintaining the logocentric framework in Stoicism, particularly in light of Whiting and Konstantakos (2018) and Long (2018). We also consider the implications that its removal might have. We do this by analysing the orthodox (logocentric) viewpoint, taking into account the criticisms 
levelled against it, and also the response that can be given to these criticisms. We also reflect on the limitations of the heterodox position (modern atheistic interpretations of Stoicism) and suggest where an integrated framework/perspective can advance Stoic environmental ethics. We do not do this with the aim of determining which view of Stoic theology is right or wrong. Rather, we aim to challenge one of the assumptions of the heterodox approach, namely that the Stoic worldview is incompatible with modern scientific thinking. Lastly, we discuss the implications of this view for the Modern Stoic movement at large, especially with regard to environmental concerns.

\section{Environmental Ethics in Stoicism}

Following the popularisation of the term "Anthropocene", in the 21st century, to refer to the geological period when humankind is a significant driver of global climatic and geological change, there is an increasing consensus that the current socioeconomic system is disrupting the Earth's delicate balance and reducing biodiversity (Haberl et al. 2007; Lewis and Maslin 2015; Rockström et al. 2009; Steffen et al. 2015, 2007; Swartz et al. 2010).

The extent of humankind's reach can be expressed by the traces we leave behind. The ancient Stoics show some awareness of this fact. This is so even though the scale of the damage done by human beings to the natural environment was far less than it is now. Seneca, for instance, shows that Stoicism can be applied to such issues when he explores the link between greed (a Stoic vice) and environmental deterioration:

"Now I turn to address you people whose self-indulgence extends as widely as those other people's greed. I ask you: how long will this go on? Every lake is overhung with your roofs! Every river is bordered by your buildings! Wherever one finds gushing streams of hot water, new pleasure houses will be started. Wherever a shore curves into a bay, you will instantly lay down foundations. Not satisfied with any ground that you have not altered, you will bring the sea into it! Your houses gleam everywhere, sometimes situated on mountains to give a great view of land and sea, sometimes built on flat land to the height of mountains. Yet when you have done so much enormous building, you still have only one body apiece, and that a puny one. What good are numerous bedrooms? You can only lie in one of them. Any place you do not occupy is not really yours.-Seneca's Letters on Ethics to Lucilius, Letter 89.20. (translated by Graver and Long 2015)

In the 21st century the problem highlighted by Seneca has increased massively. The total volume of concrete ever produced is enough to cover the entire Earth's surface with a layer two millimetres thick (Lewis and Maslin 2018). In 2010 alone, there was an estimated 75 million tonnes of plastic waste generated with 4.8 to 12.7 million tonnes entering the ocean (Jambeck et al. 2015). Cumulatively, and taking into account all possible sizes of plastic particles, there are an estimated five trillion plastic pieces weighing over 250,000 tonnes floating in the sea (Eriksen et al. 2014). In addition to choking our oceans, we acidify and heat them, which in turns lead to coral bleaching and the devastation of fish nurseries. In 1974, 10 percent of fish populations were overfished compared to 66.9 percent in 2015, despite global sustainability targets set to reverse this decline (FAO 2018; UN 2015). In 2016, approximately 80 million tonnes of fish were removed from the sea and in just 40 years, there has been a 60 percent decline in terrestrial and marine vertebrate populations (FAO 2018; WWF 2018).

Factories and farming remove the same quantity of nitrogen as all of Earth's natural processes and humans annually move more sediment, soil and rock than that which is carried off in the same year by all natural processes combined. Since the Industrial Revolution, our activities have released 2.2 trillion tonnes of $\mathrm{CO}_{2}$ into the atmosphere, which has increased the total amount in the atmosphere by 44 percent (Lewis and Maslin 2018). The trees needed to combat this phenomenon, and the associated global temperature rise, have been cut to make way for our expansion. Since the dawn of agriculture, the global forest area has almost halved and the tropical forests able to provide the greatest removal of carbon dioxide from the atmosphere are increasingly under the threat of agricultural and mining activity (FAO 2016). 
The unprecedented material wealth accumulation, far beyond the imaginations of the historic elite, has led to increasing inequality in the 21st century. Furthermore, given the existing policies and practices that advance rather than overcome economic polarity, for the poor to be bought out of poverty it will be Earth and not corporate profit margins that will need to be the most accommodating ( $\mathrm{O}^{\prime} \mathrm{Neill}$ et al. 2018; Raworth 2017). In short, we need to urgently re-evaluate our role on and relationship with Earth, living beings and planetary processes. Failure to do so will mean that humankind risks pushing the natural environment beyond the point where it can sustain life and facilitate flourishing for human and other forms of life. In this respect:

The Anthropocene is a reminder that the Holocene, during which complex human societies have developed, has been a stable, accommodating environment and is the only state of the Earth System that we know for sure can support contemporary society —Steffen et al. (2011)

The above statement, while evidently modern, is in line with ancient Stoic thought, according to which the recognition of the validity and rationality of the natural universe go hand in hand with achieving human excellence and happiness. This understanding is consistent with the Stoic idea that the goal of life is "to live according to Nature", an idea which is linked, in turn, with their pantheistic worldview. Pantheism, as a metaphysical and religious stance, can be broadly defined as a belief that "god is everything and everything is god or that the world is either identical with god or, in some way, a self-expression of his nature" (Owen 1971, p. 8).

The idea of pantheism gives us scope for exploring the implications of Stoic theology for environmental ethics, and thus for extending the limited amount of work done by modern Stoics on this topic (e.g., Gill 2014a; Konstantakos 2014; Whiting et al. 2018a, 2018b). This is because pantheist ethical frameworks generally are metaphysically founded on the unity of the divine, and the idea that this divinity is present within all its component parts. This understanding then forms the basis of extending one's notion of the moral community to non-human beings and non-living things, such as rocks (Levine 1994). Whiting et al. (2018a) expansion of the Stoic circles of concern to include the "environment", reflects this worldview, and the fact that the preceding circles (ranging from the "self" to "humanity") could not exist without the sustenance and support provided by Earth (Cf. Epictetus 1.14).

The moral obligation that comes with including the environment in the circles of concern is captured by Aldo Leopold's assertion that "a thing is right when it tends to preserve the integrity, stability, and beauty of the biotic community. It is wrong when it tends otherwise" (Leopold 2014). It also echoes the view of Stoic biologist Steve Karafit that one cannot claim to be progressing towards the goal of Stoic virtues at the cost of environmental sustainability (Karafit 2018). The rationale behind a Stoic ethics that integrates both Leopold's and Karafit's statements is that a Stoic's virtue, in order to be considered as such, must necessarily manifest itself in interactions with other living beings and the environment. This is because Nature is the ultimate reference of all evaluation and produces both facts and values. It thus states both what is the case and what ought to be the case (Long 1996b). In other words, Stoic morality is necessarily grounded in Nature. What is reasonable is not merely an action that is logical, but that which is consistent with humankind's rational and social nature.

That said, and in order to reduce any potential for misunderstanding, it is important to distinguish the Stoic sense of anthropocentric/logocentric moral obligations and that held by practitioners of Deep Ecology (see Naess 1973) or Leopold's Land Ethic (see Lenart (2010) as evaluated by Protopapadakis (2012). Here it is sufficient to say that both these approaches attempt to operate out of a biocentric (Earth-centred) model, and argue strongly against any thoughts or actions that favour humankind over any other living community. This stance is incompatible with Stoicism for various reasons. Firstly, biocentricism is rooted in a non-hierarchical reality of the universe and an ethical framework that operates according to the belief that humans are not inherently superior to any other species or the living organism that Earth constitutes (Gadotti 2008a, 2008b; Gadotti and Torres 2009; Taylor 2011). This clearly contradicts the Stoic position that humankind's rationality affords them a special place in the natural order and that Nature's providence applies in a special way to them. Secondly, the Stoic god, although traditionally considered to be a biological animal, does not share the characteristics of 
James Lovelock's Gaia, which maintains a self-regulating homeostasis but does not do so purposefully or with any sense of foresight or telos (Lovelock 1990). Thirdly, while the logos has intrinsic value, Earth as a planet, humankind, and any animal or plant, although warranting of moral consideration, do not. Lastly, a biocentric position is built on the premise that a person can see our shared planetary kinship through the "planet's eyes" and that we ought to approach norms and values from the Earth's, or at least an animal's or plant's, perspective. There is no attempt in Stoic thought to attempt to see the universe from such a perspective, since Stoics think that being human (as distinct from a non-human animal) gives us a favourable position for making sense of the universe. Although human beings are encouraged to take up "the cosmic perspective" (Marcus Aurelius, Meditations 5.24, 12.24, 9.32), this is one that human beings, as rational animals, are distinctively capable of adopting (Cicero, On the Nature of the Gods 2.37). In short, the Stoic position is, by definition, equally anthropocentric and logocentric. This is possible because we are both human and distinctively able to understand, through the logos, the rationality built into the universe because of our own rationality.

This difference between Stoicism and the modern biocentric view does not mean that there are no points of similarity. Good examples of certain shared beliefs is provided by Naess (1995, p. 14), when he asserts that we are all in, of and for Nature from the very beginning, and by Vaughan, who emphasises that pantheism "recognises both our biological and psychological dependence on the environment [and the fact that] we are actually interdependent and interconnected with the whole fabric of reality" (Devall 1995, p. 103).

This assertion aligns with Posidonius' view that the status of each limb depends on the body's overall condition, and that it is not possible for the component parts to prosper if the whole suffers (Protopapadakis 2012). Accepting the Stoic logocentric model means that looking after the planet is the manifestation of an appropriate action (kathekon), which is beneficial for its own sake, our sake and for the sake of the Universal community (Stephens 1994). In which case, modern Stoics ought to call for environmental action because to align oneself with "the will of god" (the in-built order and rationality of the universe) is good and because god commands it.

Consequently, the Stoic call to live in agreement with Nature is essential to achieving eudaimonia (human flourishing). To live in harmony with Nature is to maximise one's happiness because it is the only path that leads human beings to flourish. If we then accept that the universe is good, then living according to "the will" of the rational universe has intrinsic value. This does not mean that a person following this "will" becomes subject to the whims of a capricious being that shows favouritism to a specific tribe (or "chosen people") and who becomes pleased or angered by a person's (in)ability to live according to an ascribed set of cultural norms and mores. Nor does such a "will" disregard others out of the need for acts of arbitrary obedience and unquestioned loyalty. In fact, such prescriptions go against cosmopolitan principles and the circles of concern. Instead, living according to the Stoic god's will is expressed through the benefit that comes by harmonising one's own rational nature with the universal active principle that has made Earth conducive to the generation and maintenance of life. This remains true even if, like Marcus Aurelius, one's personal role involves leading an army into battle (e.g., Meditations, 2.5). Indeed, one's local job functions do not absolve a person from the responsibility and obligation of acting out one's civic duty, as a citizen of the universe (cf. Stephens 2011, pp. 36-39).

Human beings are not the pinnacle of existence (the logos is) but they are exceptional among all animals in that they have been bestowed with the property of rationality-a characteristic they share with god. Incidentally, it is Nature's providential care and generous provision of life that implants the instinctive desire that humans and other living beings feel when it comes to the need to preserve and take care of themselves (their nature or "constitution") and also to procreate and look after offspring and others of their kind (see Long and Sedley 1987, 57, esp. A, F(1)). In this sense, a person that follows "god's will" is simply conforming their mind and volition to the natural law that determines right thoughts and actions for them, as a member of a community uniquely equipped to understand the universe's causal structure and its beneficence to their very existence (Cf. Epictetus 1.14). The key 
question then becomes, if we reject Stoic teleology and "live according to facts", can we still come to the same conclusion? Or do we lose something in the process?

\section{Stoic Theology: A Modern Debate}

This has already been a great deal of specialist theological discussion on the ancient Stoic worldview. This section explores the extent of which modern Stoics can incorporate the Stoic worldview in a coherent ethical framework that aligns with the 21st century understanding of how the world works. We clarify the main two approaches to theology held within modern Stoicism and untangle some of the thornier issues in order to better understand the ethical claims being made.

\subsection{The Orthodox View}

Various modern Stoic scholars, most notably A.A Long, Christoph Jedan, Gisela Striker and Marcelo Boeri contend that the orthodox Stoic view is not a mere historical detail but essential to the coherence of the philosophy. Jedan (2009) argues that Stoic theology provides the rationality of apparently paradoxical claims regarding the sufficiency and "all or nothing" status of virtue. Boeri (2009) puts forward the case that ancient Stoic cosmology provides meaning to Stoic principles and points to the sheer number of texts where the origin of Stoic tenets can be explicitly traced back to the logos. Likewise, Long (1996a) asserts that the Stoic conviction regarding a human being's purpose and the attainment of eudaimonia "is principally grounded in their beliefs about the relation in which human beings stand to a determinate and providentially governed world" (Long 1968). Similar sentiments are found in Striker (1996).

Part of the unease that moderns have with the orthodox view is that this approach uses the term "theology", which in turn, invokes an association with "religion", "the nature of god" and "spirituality". It is, therefore, important that we dispel any common (and fully understandable) misconceptions moderns may have when interpreting ancient Stoic texts and their theological framework. In doing so, we hope that those readers of a more agnostic/atheistic inclination do not come to reject Stoic ideas and their applicability to environmental ethics, before they have had the time to (re)read and (re)consider them. This is particularly important because there are many modern Stoics who were originally attracted to the philosophy and its fellowships precisely because of an aversion to, or a loss of, a contemporary religious belief.

It is essential that moderns understand that the ancient Stoics would not have recognised the modern distinction between religious thought and scientific inquiry. This is why the Stoic god, as perfect rationality, has a clear philosophical basis, which necessarily must be arrived at and defended via rational argument and not faith or dogma (Clark n.d.). Furthermore, while there were certainly religious aspects, ancient Stoicism was not a religion. There was no leadership hierarchy nor was there an appointed authority, places of worship or sacred books. It was not heretical to question or reject earlier Stoic ideas on the basis of reasoned argument. Furthermore, no Stoic practitioner was seen as an apostate and ex-communicated for involving themselves in the Roman rituals and traditions (Sadler 2018). That said, the ancient Stoics, especially Chrysippus and Cornutus, did re-interpret some pre-existing and traditional Greco-Roman religious ideas in order to bring them into their logocentric worldview. The latter, which we have already briefly discussed, was a naturalistic rational framework that formed the basis of Stoic virtue ethics and provided practitioners with the rationale to study the natural world and the wider cosmos, including the celestial bodies (which were often referred to as gods). This is, in effect, what Cicero explains in On Ends (De Finibus III, 73):

Nor can anyone judge truly of things good and evil, save by a knowledge of the whole plan of nature and even of the life of the gods.

We want to make it clear that while it is true that under the modern Stoic umbrella people can refer to themselves as a Christian Stoic, a Muslim Stoic, a Hindu Stoic, a Buddhist Stoic or an atheist Stoic — as long as they accept that the four Stoic virtues are sufficient and necessary for an adult human 
being to flourish - the orthodox Stoic position is grounded in a pantheistic vision of the universe (Levine 1994; Sellars 2006). Furthermore, the immanent nature of the Stoic god will certainly conflict with the transcendental aspects of the aforementioned religious traditions, leading to, at the very least, unusual interpretations of key aspects of Christian, Muslim, Hindu or Buddhist beliefs-especially those associated with "miracles" and other supernatural events. This is because nothing outside Nature forms any part of what Stoics believe to exist. In other words, the orthodox Stoic understanding of the universe, including god, is entirely grounded in natural phenomena.

Stoic reverence for Nature or "god" does not come through any profession of faith, i.e., an affirmation dependent on the holding of a belief, such as in existence of heaven, hell, angels and other miraculous signs, even in the absence of, or contrary to, available evidence. This is clear from the Chrysippean "proofs" for the Stoic god, which are all based on reasoned argument about the nature of the universe as understood by the Stoics (Dragona-Monachou 1976, pp. 112-20). In other words, the ancient Stoics recognised, through their theology and not despite it, that progress towards virtue relied not on divine revelations from a supernatural being but on living in accordance with Nature and by the facts Nature provides.

The Stoic pantheistic vision has some unique features that distinguish it from Spinoza's god (see Long 2003) and the entity created by Arne Naess (1973). However, it also shares many aspects with modern-day movements and belief systems that emphasise the importance of leading an environmentally sensitive/sympathetic way of life. In Stoicism, this response is simply an acknowledgement that the Earth's natural system, as the giver and sustainer of life (words typically used to describe a god), is worthy of care and consideration, for its sake and our own.

The Stoic god is the universal pervasiveness of the universe's mind-its commanding faculty-and thus the force of fate and the necessity of future events (Long and Sedley 1987, 54A, 54B). It is the creator of the whole, immortal, perfectly rational, perfectly happy and perfectly benevolent-in that the universe generously provides all that is required to support life and allow that life to flourish. The Stoic god is provident toward the world and its occupants and does not create or admit the existence of evil. It is not anthropomorphic, but it does exercise an anthropocentric divine providence, which is best understood by humankind through carefully and methodically observing Nature, which reveals its divinity (perfect rationality) in physical processes, i.e., scientific facts (Baltzly 2003). God's body is finite, insofar as the cosmos is finite (Aetius I, $6=$ SVF 2.528) and made of a physical creative fire or physical breath. Furthermore, like the rest of creation, the Stoic god is a soul-body composite made up of a passive principle ("matter" or "substance without quality") and an active principle (logos, which was likewise corporeal).

The Stoic god's acts and intentions are not specific to an individual, or a group of individuals. Instead, they operate in line with natural causality and reflect the providentially and fatally ordered sequence of causes and effects in the cosmos-an inescapable and inevitable law of what exists (Inwood and Gerson 1997). There are no divine interventions, so no favouritism and no miracles (Algra 2003). Other than thinking and acting rationality in accordance with Nature, so that one can progress towards a eudaimonic state, there are no prescribed acts or words of "worship". There is no way to "please" or "anger" the Stoic god. There is no divine judgement and god does not send souls to a "heaven" or "hell". In fact, other than certain speculations regarding the wisest of humans (the sages), the soul, as a physical component of the body, does not survive death (Jedan 2009; Lagrée 2016).

This is what orthodox modern Stoic Chris Fisher (2016) explains, when reflecting on Seneca's On Providence, 2.4:

Stoics viewed Nature as benevolent—conducive to human life. Death, disease, and natural disasters are not punishments from an angry God; they are simply the natural unfolding of events within a web of causes, often outside of our control. Stoics accept that the cosmos is as it should be and they face challenging events as opportunities for growth rather than considering them harmful. This is neither resignation nor retreat from the realities of human existence. Stoics strive to do all we can to save lives, cure disease, and understand and mitigate natural and man-made disasters. 
It is within this frame of reference, that ancient and orthodox modern Stoics agree that there are objective moral facts, i.e., that some kinds of actions are right and others wrong, independent of what a human being thinks or decides. If this were not so, Stoics could not explain how it is possible that an individual who has perfected their moral reason (referred to as a sage) is said to be incapable of a moral mistake.

The Stoic teleological worldview is evidently and explicitly associated with Chrysippus' dictum that living in agreement with Nature means engaging in no activity which the common law (god) forbids. Furthermore, the excellent character (arete) of a flourishing agent (eudaimon) consists in being in concordance with "the will of the universe". In which case, as Long (1996b) points out, the theocratic postulate is integral to the Stoic conception of virtue, and in understanding how virtue is sufficient and necessary for eudaimonia. In a Stoic framework, this requires knowledge of Nature (which is accessed via "physics" and theology) and those morally correct actions (katorthomata) that necessarily cohere with Nature. It follows that those modern Stoics who promote a theological approach to morality do so because they believe that the logocentric worldview roots facts in a unified cosmic framework and is thus the reason behind the Stoic call to live according to Nature. In turn, they maintain that Nature provides the facts and the corresponding values for normative decision making. Indeed, even if an atheistic-leaning Stoic does show that there is a mechanistic non-rational ordering of the universe that does not mean we should value it, as we will explore in more detail in Section 4.

In short, the orthodox Stoic position holds that facts are not the end but rather the means with which to seek harmony with the universe and reason, because the logos is an intrinsic good. They also point to Nature's providential care as the basis for the Stoic cosmopolitan ethical framework and the Stoic metaphor of the circles of concern, which conceptualise the appropriateness of looking after the self, other members of the universal human tribe and the environment.

\subsection{The Heterodox View}

Breaking away from certain aspects of Stoic theology/cosmology is not something that is restricted to modern philosophers. The ancient Stoic Panaetius, for example, rejected some aspects of Stoic theology, namely divination and the conflagration (cataclysmic end of the cosmos when all becomes fire), while retaining the Stoic position overall (Testimonia 130-140). Likewise, neo-Stoics such as Justus Lipsius and Francis Hutcheson rejected elements of Stoic cosmology in favour of Christian doctrine (Maurer 2016). Lipsius, for example, argues among other things, that the Stoics are wrong to claim that the sage is superior to god, a position justified by their belief that a Stoic practitioner relies on their own efforts, whereas god is virtuous by nature (Man. 3.14, as paraphrased by Lagrée 2016). In our opinion, while there is nothing wrong with rejecting certain elements of Stoic theology as untenable, one must be careful to ensure that if some Stoics reject the philosophy's theological premise in its entirety that their reasons are valid. It also means that whatever replaces it must be consistent and coherent with the uniquely Stoic idea that virtue is the one true "good" and the only thing that is both necessary and sufficient for human happiness.

The heterodox modern Stoic view is an atheistic-agnostic ethical framework. It attempts to provide normative values without reference to Stoic theology. Modern Stoics that hold to this position do so for various reasons. One of them is linked to the issue that moderns have with the Western perception of god (not just the Stoic one) and the concept's relevance or role in explaining phenomena in the natural world (Cf., LeBon 2014). As we have already discussed, this discomfort is derived from a cultural understanding of "god" which is dominated by monotheistic interpretations and the superstitious and supernatural baggage that such beliefs imply. The Stoic god most definitely does not coincide with Abrahamic creation myths, nor its descriptions of god's anthropomorphic character (i.e., angry or jealous) that leads to his capricious actions and an arbitrary or punitive Will. We have also shown that Stoic theology is more like (modern) science than other theological perspectives because the material Stoic god is more aligned with what atheists or agnostics might refer to as the "scientific worldview". 
This brings us to a second, and much more difficult and nuanced, topic to address, which is whether moderns can accept the Stoic's naturalist theological framework, as a credible scientific account of the natural world. Many leading modern Stoic scholars, such as Lawrence Becker (Becker 2017, p. 6) and Massimo Pigliucci (Pigliucci 2017a) argue that we cannot. They contend that, if the integrity of modern Stoicism is to remain intact, we must necessarily make the case that Stoic ethics can be upheld without the need for cosmic teleology. This is in essence why Annas $(2007,1995)$ and Inwood (2003) argue that recovering the Stoic theological framework in a modern context would ultimately be a mistake.

Becker $(2017,1998)$ tries to flesh out the practice of Stoic ethics in the modern world. He adopts an atheistic approach in which he replaces the cosmological foundations of the call to "live according to Nature" with an ethical framework built on a call to "live according to the facts". He states that:

Following nature means following the facts. It means getting the facts about the physical and social world we inhabit, and the facts about our situation in it-our own powers, relationships, limitations, possibilities, motives, intentions, and endeavours - before we deliberate about normative matters. It means facing those facts-accepting them for exactly what they are, no more and no less-before we draw normative conclusions from them. It means doing ethics from the facts—constructing normative propositions a posteriori. It means adjusting those normative propositions to fit changes in the facts. (Becker 2017, p. 46)

In rejecting the Stoic linkage between Stoic ethics and cosmology, Becker assumes that Stoic theology, in the ancient world, did not aim to "face the facts". However, this is mistaken. Stoic theology, and ethics, were supposed by ancient Stoics to be consistent with 'the facts', as they understood them, that is the facts about the nature of the universe and the place of human beings and other animals within the universe. Therefore, the position Becker adopts-while presented as being a radical revision of the Stoic view-is actually in line with it. Furthermore, Stoic principles stipulate that practitioners have an obligation to address discrepancies where ancient beliefs contradict modern discoveries or are challenged by scientific pursuits. In other words, Stoic theology is not opposed to the scientific view, but depends on it.

Having identified this source of confusion, it is worth clarifying what exactly is being argued in the modern heterodox call to "follow the facts". The crux of the issue does not boil down to whether Stoics should follow facts (they evidently should) but whether the orthodox Stoic worldview is an accurate depiction of the facts, as these are understood in the modern world. The question at hand is whether or not it is acceptable for moderns to operate out of the orthodox understanding that the universe acts with benevolent providence, that the logos is an intrinsic "good" and that it dictates what is virtuous, vicious or neither.

For many prominent modern Stoics, including Lawrence Becker, Massimo Pigliucci, Greg Lopez and Piotr Stankiewicz (see Stankiewicz 2017, for example), the heterodox worldview is compatible with modern science precisely because, unlike the orthodox position, it does not claim that the universe is good or that it provides objective meaning. For such Stoics, the universe is understood as being mechanistic (quantistic-relativistic). It is most definitely not benevolent and certainly does not work for the benefit of humankind (Pigliucci 2017a). Consequently, the logos is re-envisioned, or re-defined, as "the (factual) observation that the universe is indeed structured in a rational manner" (Pigliucci 2017c).

For heterodox Stoics, given that meaning does not exist objectively, it is simply something that humans construct as social and intelligent beings. It follows that what an individual neurotypical human being ought to do can be derived from facts about human values, preferences, historical events, cultural norms and social conventions (Becker 2017). These facts are not derived from what an orthodox Stoic refers to when they speak of "living according to Nature", but instead from our collective accounts of human psychology, history, sociology and biology. Contrary to the orthodox position, there is no absolute moral truth (orthodox Stoics would contend that it is the goodness inherent in the immanent law of Nature) and no objective good outside of human perception. In other 
words, "virtue" is not an objective intrinsic property of Nature but depends solely on human thought and action. This is effectively what Pigliucci (2017a) implies:

The idea of mind independent moral truths is rejected as incoherent since ethics is the study of human prescriptive actions. Conversely, relativism is also a no starter because there are objective facts about human nature and the human condition that constrain our ethical choices.

Massimo Pigliucci is certainly right (and in line with ancient Stoicism) in arguing that we should aim to make decisions based on an objective understanding of human nature. After all, we are compelled by certain facts and lack the absolute freedom to choose which facts are valuable to us (e.g., pain, hunger or thirst). Likewise, our capacity for rationality causes us to become aware of other types of facts, such as climate change. Once we are aware of climate change, we are then consciously and rationally compelled to understand this fact for the sake of our own good (Butman 2019). The problem with Pigliucci's (2017a) statement and Becker's $(1998,2017)$ view on 'facing the facts' is that while there may be some connections between facts and norms, for many moderns, including those in the heterodox camp, it is a fallacy to believe that one can derive values from them (Hume 2006; Moore 1959). It is also important to recognise that the ancient Stoics did not reduce Physics to "fact hunting" because they were aware that what they might consider a fact might not be. This is the reason why Stoics say that when facts are unclear, but the impression is such that it is reasonable to believe them, then we should only assent to the impression that it is reasonable to believe, and not assert that such and such is the case. In other words, we should assent with reservation as Sphaerus did with the pomegranate (as explained by Diogenes Laertius in the Lives of the Eminent Philosophers, Book 7, 177). Furthermore, if we see the world only through the lens of facts, we tend to see things from a reductionist perspective. The latter can have and has had grave consequences for the natural world, which is far more complex than we can understand and does not thrive when reduced to its component parts (Long 2018).

Ethics are not only concerned with human actions towards other humans, but also with how the world and non-humans operate. Our freedom to imbue facts with meaning is conditioned by the fact that we live in the world, which is not only dependent on human nature but Nature generally. Together, they both determine the attitude a person ought to have and what action they ought to take. This is why orthodox Stoics maintain that it is in aligning one's behaviour with how the world works which is conducive to human happiness.

Another major difficulty that surfaces when appealing to the objectivity of facts is that while they can help an individual decide what to think or how to act, they have no bearing, in and of themselves, on whether that thought or act is virtuous or not. To infer virtue or vice from scientific facts requires a proxy ideal for virtue in the objective sense. One way to interpret the heterodox view of virtue is through "harmony", which is a particularly appropriate Stoic proxy for wellbeing. This is because it incorporates both societal structures and the natural world. Striving for a personal sense of harmony provides meaning for an individual looking to navigate an indifferent universe. In this respect, it would not matter if a person is aligned with the nature of the universe, as it is that person's sense of harmony or discord that determines their progress towards eudaimonia. In other words, one can make the case that a Stoic could determine the virtuousness of their thoughts, acts or mental state by gauging how much harmony was created or destroyed either in themselves or within, or between, any of the other relationships represented by the concentric circles of concern. If this is true, Annas (1995) is correct to assert:

If I am convinced that virtue is sufficient for happiness, then when I acquire the cosmic perspective I acquire the thought that this is not just an ethical thesis, but one underwritten by the nature of the universe. But what actual difference can this make? It cannot alter the content of the thought that virtue suffices for happiness, for I understood that before if I understood the ethical theory. Nor is it easy to see how the cosmic perspective can give me any new motive to be virtuous; if I understood and lived by the ethical theory, I already had sufficient motive to be virtuous, and if awareness of the 
cosmic perspective adds any motivation then I did not already have a properly ethical perspective before. -(Annas 1995, p. 166)

Arguably, the biggest challenge to the heterodox position is revealed when attempting to apply harmony as a proxy for societal/planetary wellbeing. For societal issues, this would entail the use of social cohesion as an indicator of the appropriateness of a given thought or action. However, when we equate social harmony with virtue as derived from facts about human values, preferences, historical events, cultural norms and social conventions, we need to recognise that these facts (unlike the essence of Nature) change. Indeed, one of the biggest factors that separate humans from other animals is cumulative culture. The latter describes our unique ability to take advantage of the scientific knowledge and philosophical ideas that are only made possible by our ability to understand and make use of the imparted knowledge and artefacts of others (Caldwell and Millen 2008; Whiting et al. 2018c). It explains why social structures and values evolve for humankind while for other animals they do not.

A good example of the problem of relying on societal values to determine virtue is the concept of slavery. The latter was commonplace in the ancient world. Incidentally, two powerful Roman Stoics, Seneca and Marcus Aurelius were well placed to modify this practice. They chose not to. Furthermore, their respective writings that now form the Stoic "canon" show that they accepted slavery as an indifferent circumstance (though not one that was preferable), and believed that it was in the treatment of the slave that virtue could be found. Seneca for example, remarks to Lucilius that:

I do not wish to involve myself in too large a question, and to discuss the treatment of slaves, towards whom we Romans are excessively haughty, cruel, and insulting. But this is the kernel of my advice: Treat your inferiors as you would be treated by your betters. In addition, as often as you reflect how much power you have over a slave, remember that your master has just as much power over you. -Seneca, Moral letters to Lucilius, Letter 47, Chapter 4

Evidently for these Roman Stoics, justice and self-control consisted of treating a slave with kindness, not using them sexually, allowing them to eat at the dinner table and remembering their humanity. It would be very difficult to maintain this position now. This means that either enslaving others was always vicious - even if the Romans did not realise it or could do nothing about it - or that, given the social norms and preferences of Ancient Rome, slavery was acceptable for ancient Roman Stoics but is wrong for modern ones (for a more detailed discussion on the ancient Stoic position on slavery (see Robertson 2017).

An orthodox modern Stoic can claim that slavery is objectively unjust regardless of spatiotemporal circumstances. That is, if Roman society required forced labour to function then that structure was not formed in accordance with Nature and those Romans were therefore vicious, regardless of any particular opinion or set of opinions. On the contrary, this is where heterodox Stoics reach an impasse. For if virtue is derived through human social mechanisms, and societal harmony is the litmus test for virtue, then banning slavery would have been unjust because it would have resulted in social breakdown, if not chaos. Additionally, and problematically for anyone looking to "live according to the facts", there are no facts that state that slavery is bad from a Stoic perspective. One might infer that it is vicious because pain or harm is being caused, but this would be a Utilitarian argument and not a Stoic one given that Stoic principles hold that pain and harm do not prevent a person from flourishing, and therefore do make the moral difference (although the reasons for inflicting pain do make a moral difference).

In this respect, the orthodox framework is far from redundant because it stipulates an objective universal reference point that dictates how we all should live, regardless of how human beings think and act. In which case, Stoic theology can inform us on what we, as a society, ought to do. 


\section{Stoic Theology: Implications for Environmental Ethics}

The call to "live according to Nature" is a fundamental principle of Stoic philosophy. It is not restricted to moral duties (which would be a deontological position) but extends to one's thoughts and mental states. In other words, flourishing is not the mere performance of appropriate actions (kathekonta), since these can be accomplished without a virtuous character. Hence why Stoics stipulate that the wise person is happy because he or she does the right action for the right reason and this right reason stems from a virtuous disposition, which is necessarily aligned with the universal causal principle (god).

Nature is the sine qua non for the evaluation of reason and no reasonable proposition can exist or be understood outside of it. Nature is also the cause of knowledge and truth. It is the basis for everyone's (and everything's) being and reality. Even moral truths, which are not founded on scientific fact, but rely on coherence or intuition, are grounded in the subjective experience of our own nature and the objectivity of the natural world generally. This reality helps us understand that we are all part of Nature, as an interconnected and interdependent web of connections that we cannot separate ourselves from. Instead, what sets humans apart is a rationality that enables us to glean divine wisdom, and absolute truth, in the form of natural laws. In contrast, all other members of the Whole have no choice but to live in harmony with the logos. In other words, our uniqueness as a species comes in our capacity to choose not to live accordance with Nature (Butman 2019).

Many moderns have used our species' innate characteristics to construct and transmit rationalising narratives that have caused many of us to give assent to the false impression that we have tamed Nature. Such stories have also led to the fallacious declaration that through our technology and ingenuity we have "risen above" the physical limits that were imposed on us, and have successfully distanced, or removed ourselves from "god's" grasp (Illich 1983; Whiting et al. 2018a). However, all we have done in reality is encroach upon those spaces previously occupied by non-Westernised communities, animals, plants and geological formations until we have undermined or negated their capacity to exist- to our great shame and loss (as we saw in Section 2).

The wanton environmental devastation that has become a feature (read collateral damage) of the human values, preferences and commitment to the present socioeconomic system underlines why greed and injustice are considered Stoic vices (made manifest in the absence of self-control and/or justice). It also gives credence to the idea that there is value in operating under the Stoic theological premise. The latter, as with all theological perspectives, provides humankind with an objective yardstick with which to frame and measure our morality. Despite what some moderns may claim, ethics is not just a matter of how we behave towards other human beings, but also necessarily involves the environment of which we are all part. In this respect, the call to "live according to Nature", far from being outdated or archaic, as many heterodox leaning Stoics claim, is actually refreshingly contemporary. It provides the tools, scope and urgency with which to deliver a far more considerate and dynamic ethical framework for the 21st century. It is exactly what we need to (re)consider and (re)contextualise the preferences, practices, policies, historical events, cultural norms, social conventions and human values that have caused the West to disregard planetary wellbeing, cause carbon emissions to climb and led to socioenvironmental inequality (as highlighted by IPCC 2018; Lent 2017; Raworth 2017; Steffen et al. 2015).

There is nothing wrong with global warming or environmental damage according to "the facts". In addition, these, in and of themselves, simply constitute a non-normative truth. That said, facts are integral to Stoic environmental ethics because they unequivocally demonstrate that carbon emissions have risen sharply since the Industrial Revolution and that, among other things, Earth is experiencing huge biodiversity loss. They indicate that the current socioeconomic system and its technologies have brought millions of people out of poverty and allowed them to rise above the drudgery of subsistence farming and some of the most arduous of domestic chores. They also tell us that one half of the world's energy is used by one-seventh of its population (Rosling 2010). In other words, isolated facts state that environmental damage has occurred or that animals have died. They show that a small minority of 
people use most of the world's resources and that the ability to substitute muscle power with fossil fuels has freed those same people to live without fear of local weather anomalies and do more than housework. However, no fact can tell us what we ought to do when two sets of facts are juxtaposed, such as the carbon emission rises associated with the increased use of home appliances and the poverty that people are almost always guaranteed without them. The facts cannot tell us whether a British CEO should reduce their reliance on electronic gadgets (at the expense of comfort and convenience) or whether a rural South American villager should instead be denied the opportunity to progress. Indeed, one can even use isolated facts (in a Utilitarian fashion) to surmise that this British CEO should be absolved from personal responsibility because he or she will make more of a net positive impact to planetary wellbeing than a village of South American farmers who suddenly do not have to wash their clothes by hand.

Even when collective decisions align with some (or even all) of humanity's current values and preferences, this does not mean that these align with courage, justice, temperance or wisdom, as is objectively understood when viewing the world through the dual anthropocentric/logocentric lens. Operating with the mind's eye fixed on the objective yardstick that orthodox theology provides, gives us an ethical imperative to express our values and virtues not just relative to each other but in respect to the Whole. It is this understanding that underpins many of our cosmopolitan ideas. The latter allow us to recognise our obligations towards indigenous and vulnerable communities that either do not ascribe to, or do not benefit from, Western ideals and systems. This is especially true if we accept that the "environment" forms the last concentric ring of the modern set of Stoic circles of concern. The addition of the "environment" then highlights the need for an ethical framework that considers planetary processes beyond any reductionist commitment to a set of facts.

Under a cosmopolitan ideal, we can understand that what makes global warming wrong is our rational desire to make the planet more hospitable to ourselves and future generations (including those born today). We can point to the virtue of resisting engagement with those activities that increase our personal carbon or water footprint. We can support the school climate strikes because the children (and parents) undertaking them are challenging the ignorance of climate denial and those policies that exacerbate climate breakdown, despite various warnings from both Nature and the scientific community (Thunberg 2018). We can see why we should collectively challenge certain pursuits that put profit before socioenvironmental justice or wise decision-making (Lane 2012). In other words, once we understand the call to live according to Nature, we can question the virtue-signalling of politicians condemning climate strike truancy rather than addressing the real environmental issues at stake.

In short, the orthodox Stoic position promotes an understanding that facts are not the end but rather the means with which to seek harmony with the universe and reason, which is encompassed by the logos, as an intrinsic good. Arguably, this reality becomes clearer once modern Stoics understand the relevance of Stoicism as a political philosophy and not just a personal one limited to dealing with one's emotions and the dichotomy of control. In this regard, Stoic theology is revealing, because it can guide modern Stoics dealing with the socioenvironmental challenges of the 21st century and in the building of the coherent ethical framework that this entails (Figure 1). 


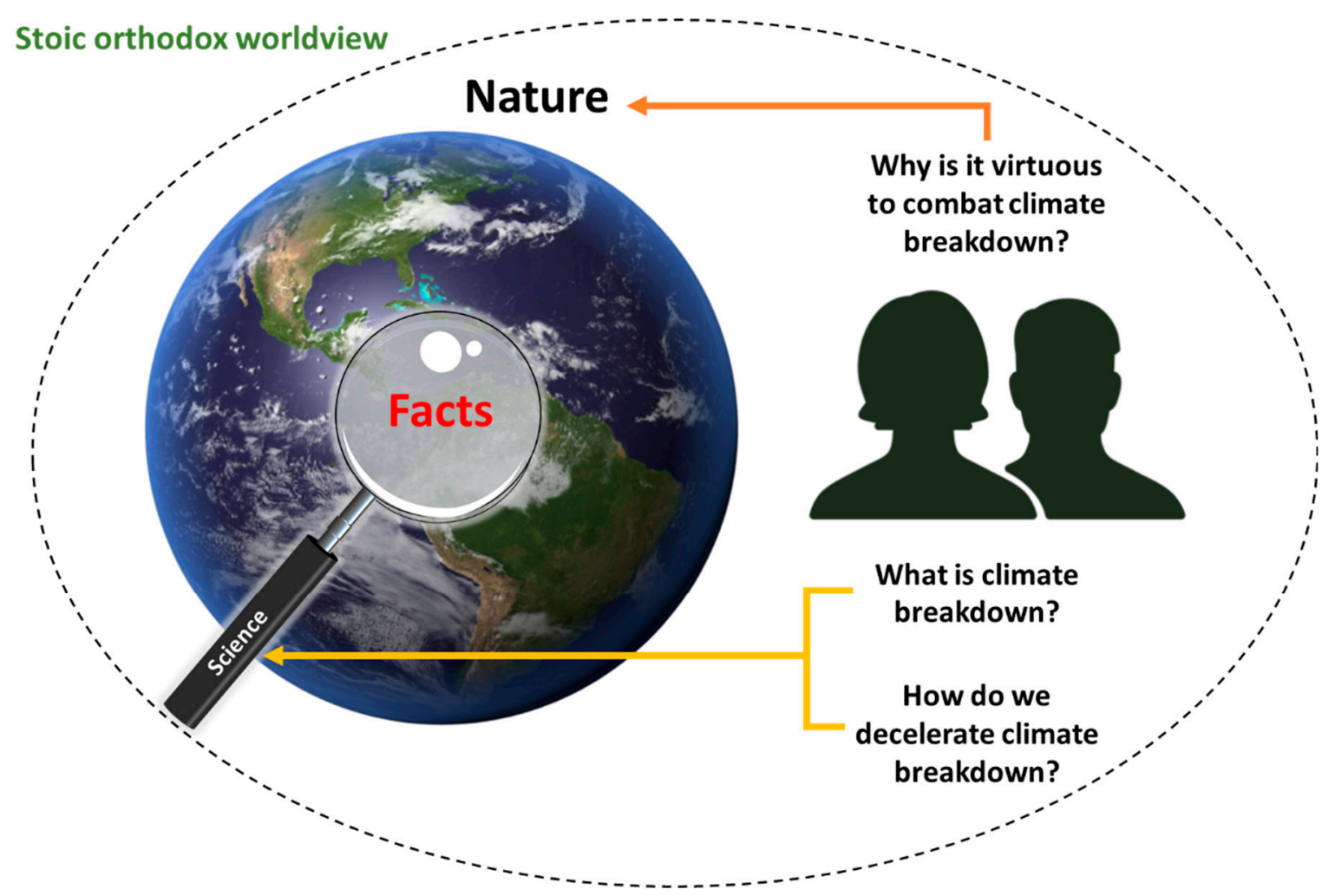

Figure 1. Stoic orthodox theology applied to environmental ethics.

\section{Final Remarks}

Overall, the case made here is that one must be mindful of the fact that all beings equally partake in what humans seem to believe, or assume to be, a rationally ordered universe. Thus, a heterodox Stoic must concede that rational humans, if programmed to look for, and operate under, patterns, flourish when they live according to what they perceive to be a rationally ordered universe. This is regardless of whether that universe is rational or not, or if they are mistaken about the nature of the pattern. It follows then that to live according to this fact is tantamount to human happiness (eudaimonia), as is recognising the interconnectedness of Nature. In other words, our flourishing is dependent on our capacity to bring ourselves in line with Nature as a whole and our own particular nature as an idiosyncratic human being (Diogenes Laertius 7.85-6 = LS 63 C). Where Lawrence Becker succeeds is in clarifying the value of the scientific method and the pursuit of facts in the modern context, which might be overlooked in a call to "live according to Nature":

[We should] get the facts about the physical and social world we inhabit, and the facts about our situation in it-our own powers, relationships, limitations, possibilities, motives, intentions, and endeavours - before we deliberate about normative matters. —Becker (2017, p. 46)

The Stoic idea of god, for the reasons stated above, does not, for the most part, contradict scientific pursuits. Rather, it serves to correct misapplications of these endeavours. In addition, Stoic principles dictate that when ancient Stoic beliefs (e.g., animals solely exist for humankind's benefit) contradict modern discoveries we have an obligation to address such discrepancies. This does not negate the value of cosmic sympathy as derived by Stoic teleology. Rather it allows a practitioner to not give assent to false impressions and brings the philosophy and its practitioners in line with the rational will of a benevolent universe. It does this by providing meaning to our pursuits, which includes directing science (and the humanities) towards research that benefits the Whole.

Part of the issue that moderns have with the Stoic god is derived from the West's cultural understanding of monotheism, which as we have made clear in this paper does not form the basis of 
the Stoic god. Conversely, it explains why a religious Stoic must give up the alleged transcendental god for an immanent one. While such terminology may make moderns uncomfortable, this is not the first time that Stoic ideas, such as women being educated or Zeno's view that both heterosexual and homosexual relationships are acceptable, have clashed with popular sensitivities. These perspectives have since been vindicated in the West and are foundational to the cosmopolitan principles of the philosophy. The historical removal of these ideas on the grounds that some people felt uncomfortable would have compromised the integrity of Stoic philosophy and the coherence of Stoic axiology. The same can be said for the modern claim that the Stoic orthodox position is untenable or unpalatable. In which case, the removal of Stoicism's theological component to protect academic sensibilities and suit a modern practitioner's palate is not just unjustified but troubling. It also, as we have shown, prevents Stoics from connecting with environmental ethics on their philosophy's own terms. Stoic rationalism implies living according to Nature, so if we are ruining the planet, we are not acting rationally, and thus not operating virtuously. Finally, whether or not Stoic theology provides the most accurate description of the universe, it still forces a different view from that propagated by those that put profits before people and the planet. It offers an underlying ethos and ethical framework that could play a critical role in how Stoics go about reversing the climate breakdown and environmental damage that the current geopolitical worldview and socioeconomic system are all but ignoring, if not accelerating.

Author Contributions: K.W. conceived this paper, led the narrative framing and coordinated its writing. L.K. provided extensive feedback and support on the Stoic sections.

Funding: K.W. acknowledges the financial support of the Fundação para a Ciência e a Tecnologia (FCT) and MIT Portugal Program through the grant PD/BP/113742/2015.

Acknowledgments: We thank Chris Gill and A.A Long for their helpful comments, suggestions and advice. We also appreciate the time taken by Jeremy Butman to comment on this paper. Lastly, we acknowledge the lifetime work of Lawrence Becker, especially, in establishing a form of Stoicism for the 20th and 21st centuries. Without his efforts this would not have been possible.

Conflicts of Interest: The authors declare no conflict of interest.

\section{References}

Algra, Keimpe. 2003. Stoic theology. In The Cambridge Companion to the Stoics. Edited by Brad Inwood. Cambridge: Cambridge University Press.

Annas, Julia. 1995. The Morality of Happiness. Oxford: Oxford University Press.

Annas, John. 2007. Ethics in stoic philosophy. Phronesis 52: 58-87. [CrossRef]

Baltzly, Dirk. 2003. Stoic pantheism. Sophia 42: 3-33. [CrossRef]

Becker, Lawrence C. 1998. A New Stoicism, 1st ed. Princeton University Press: Princeton.

Becker, Lawrence C. 2017. A New Stoicism: Revised Edition. Princeton: Princeton University Press.

Boeri, Marcelo. 2009. Does Cosmic Nature Matter? In God and Cosmos in Stoicism. Edited by Ricardo Salles. Oxford:

Oxford University Press, pp. 173-200.

Butman, Jeremy. 2019. Personal Correspondence, January 11.

Caldwell, Christine A., and Ailsa E. Millen. 2008. Studying cumulative cultural evolution in the laboratory. Philosophical Transactions of the Royal Society B: Biological Sciences 363: 3529-39. [CrossRef]

Clark, James. n.d. How does the Cosmogony of the Stoics relate to their Theology and Ethics?

De Waal, Frans. 2010. The Age of Empathy: Nature's Lessons for a Kinder Society. New York: Broadway Books.

Devall, Bill. 1995. The Ecological Self. In The Deep Ecology Movement: An Introductory Anthology. Edited by Alan Drengson and Yuichi Inoue. Berkeley: North Atlantic Books, pp. 13-30.

Dragona-Monachou, Myrto. 1976. The Stoic Arguments for the Existence and the Providence of the Gods. Athens: National and Capodistrian University of Athens.

Eriksen, Marcus, Laurent CM Lebreton, Henry S. Carson, Martin Thiel, Charles J. Moore, Jose C. Borerro, Francois Galgani, Peter G. Ryan, and Julia Reisser. 2014. Plastic pollution in the world's oceans: More than 5 trillion plastic pieces weighing over 250,000 tons afloat at sea. PLoS ONE 9: e111913. [CrossRef] [PubMed] 
FAO. 2016. State of the World's Forests 2016. Forests and Agriculture: Land-Use Challenges and Opportunities. Rome: Food and Agriculture Organization of the United Nations.

FAO. 2018. The State of World Fisheries and Aquaculture 2018: Meeting the Sustainable Development Goals. Rome: Food and Agriculture Organization of the United Nations.

Fisher, Chris. 2016. The Path of the Prokopton-The Discipline of Desire. Available online: http://www. traditionalstoicism.com/the-path-of-the-prokopton-the-discipline-of-desire/ (accessed on 5 February 2019).

Gadotti, Moacir. 2008a. Education for sustainability: A critical contribution to the Decade of Education for Sustainable development. Green Theory and Praxis: The Journal of Ecopedagogy 4: 50. [CrossRef]

Gadotti, Moacir. 2008b. Education for Sustainable Development: What We Need to Learn to Save the Planet. Sâo Paulo: Instituto Paulo Freire.

Gadotti, Moacir, and Carlos Alberto Torres. 2009. Paulo Freire: Education for development. Development and Change 40: 1255-67. [CrossRef]

Gill, Christopher. 2014a. Stoicism and the Environment. In Stoicism Today: Selected Writings. Edited by Patrick Ussher. Exeter: Stoicism Today Project.

Gill, Christopher. 2014b. What is Stoic Virtue? In Stoicism Today: Selected Writings. Edited by Patrick Ussher. Exeter: Stoicism Today Project.

Graver, Margaret, and Anthony A. Long. 2015. Seneca: Letters on Ethics: To Lucilius. Chicago and London: The University of Chicago Press.

Haberl, Helmut, K. Heinz Erb, Fridolin Krausmann, Veronika Gaube, Alberte Bondeau, Christoph Plutzar, Simone Gingrich, Wolfgang Lucht, and Marina Fischer-Kowalski. 2007. Quantifying and mapping the human appropriation of net primary production in earth's terrestrial ecosystems. Proceedings of the National Academy of Sciences USA 104: 12942-47. [CrossRef] [PubMed]

Hume, David. 2006. An Enquiry Concerning the Principles of Morals. Oxford: Oxford University Press.

Illich, Ivan. 1983. Deschooling Society, 1st ed. Harper Colophon: New York.

Inwood, Brad, ed. 2003. The Cambridge Companion to the Stoics, Cambridge Companions to Philosophy. Cambridge: Cambridge University Press. [CrossRef]

Inwood, Brad, and Lloyd P. Gerson. 1997. Hellenistic Philosophy: Introductory Readings. Indianapolis: Hackett Publishing. IPCC. 2018. Summary for Policymakers. In Global Warming of $1.5^{\circ}$ C.. An IPCC Special Report on the Impacts. Geneva: Intergovernmental Panel on Climate Change.

Irvine, William B. 2008. A Guide to the Good Life: The Ancient Art of Stoic Joy. Oxford: Oxford University Press.

Jambeck, Jenna R., Roland Geyer, Chris Wilcox, Theodore R. Siegler, Miriam Perryman, Anthony Andrady, Ramani Narayan, and Kara Lavender Law. 2015. Plastic waste inputs from land into the ocean. Science 347: 768-71. [CrossRef]

Jedan, Christoph. 2009. Stoic Virtues: Chrysippus and the Religious Character of Stoic Ethics. New York: Continuum.

Karafit, Steve. 2018. 67: Taking Stoicism Beyond The Self with Kai Whiting in The Sunday Stoic Podcast. Available online: https: / / www.youtube.com/watch?v=HB1zYYJwBP8\&t=1s (accessed on 5 February 2019).

Konstantakos, Leonidas. 2014. Would a Stoic Save the Elephants? In Stoicism Today: Selected Writings. Edited by Patrick Ussher. Exeter: Stoicism Today Project.

Lagrée, Jacqueline. 2016. Justus Lipsius and Neostoicism. In The Routledge Handbook of the Stoic Tradition. Abingdon: Routledge, pp. 683-734.

Lane, Melissa S. 2012. Eco-Republic: What the Ancients Can Teach Us about Ethics, Virtue, and Sustainable Living. Princeton: Princeton University Press.

LeBon, Tim. 2014. The Argument Against: In Praise of Modern Stoicism. Modern Stoicism. Available online: https: / / modernstoicism.com/the-debate-do-you-need-god-to-be-a-stoic/ (accessed on 7 December 2018).

LeBon, Tim. 2018. 6 Years of Stoic Weeks: Have we Learnt so far? Available online: http:/ /www.timlebon.com/ Stoic\%20Week\%202018\%20Research\%201.0.pdf (accessed on 5 February 2019).

Lenart, Bartlomiej. 2010. Enlightened self-interest: In search of the ecological self (A synthesis of Stoicism and ecosophy). Praxis 2: 26-44.

Lent, Jeremy. 2017. The Patterning Instinct: A Cultural History of Humanity's Search for Meaning. New York: Prometheus Books.

Leopold, Aldo. 2014. The land ethic. In The Ecological Design and Planning Reader. Edited by Forster O. Ndubisi. Berlin/Heidelberg: Springer, pp. 108-21.

Levine, Michael P. 1994. Pantheism, ethics and ecology. Environmental Values 3: 121-38. [CrossRef] 
Lewis, Simon L., and Mark A. Maslin. 2015. Defining the anthropocene. Nature 519: 171. [CrossRef]

Lewis, Simon L., and Mark A. Maslin. 2018. The Human Planet: How We Created the Anthropocene. London: Penguin. Long, Anthony A. 1968. The Stoic concept of evil. The Philosophical Quarterly 18: 329-43. [CrossRef]

Long, Anthony A., ed. 1996a. Stoic Eudaimonism. In Stoic Studies. Cambridge: Cambridge University Press, pp. 179-201.

Long, Anthony A. 1996b. Stoic Studies. Cambridge: Cambridge University Press.

Long, Anthony A. 2002. Epictetus: A Stoic and Socratic Guide to Life. Oxford: Clarendon Press.

Long, Anthony A. 2003. Stoicism in the Philosophical Tradition. In The Cambridge Companion to the Stoics, Cambridge Companions to Philosophy. Edited by Brad Inwood. Cambridge: Cambridge University Press, pp. 365-92. [CrossRef]

Long, Anthony A. 2018. Stoicisms Ancient and Modern. Modern Stoicism. Available online: https:// modernstoicism.com/stoicisms-ancient-and-modern-by-tony-a-a-long/ (accessed on 7 December 2018).

Long, Anthony A., and David N. Sedley. 1987. The Hellenistic Philosophers: Volume 1, Translations of the Principal Sources with Philosophical Commentary. Cambridge: Cambridge University Press.

Lopez, Greg. 2018. Stoic Fellowship_Current Members 8th November 2018. Personal Correspondence.

Lovelock, James E. 1990. Hands up for the Gaia hypothesis. Nature 344: 100. [CrossRef]

Maurer, Christian. 2016. Stoicism and the Scottish Enlightenment. In The Routledge Handbook of the Stoic Tradition. Edited by John Sellars. Abingdon-on-Thames: Routledge, pp. 254-69.

Moore, George E. 1959. Principia Ethica: (1903). Cambridge: Cambridge University Press.

Naess, Arne. 1973. The shallow and the deep, long-range ecology movement. A summary. Inquiry 16: 95-100. [CrossRef]

Naess, Arne. 1995. Self-realization. An ecological approach to being in the world. In The Deep Ecology Movement: An Introductory Anthology. Edited by Alan Drengson and Yuichi Inoue. Berkeley: North Atlantic Books, pp. 13-30.

O’Neill, Daniel W., Andrew L. Fanning, William F. Lamb, and Julia K. Steinberger. 2018. A good life for all within planetary boundaries. Nature Sustainability 1: 88. [CrossRef]

Owen, Huw Parri. 1971. Concepts of Deity. Berlin/Heidelberg: Springer.

Pigliucci, Massimo. 2017a. Becker's A New Stoicism, II: The Way Things Stand, Part 1. How to Be a Stoic. Available online: https:/ /howtobeastoic.wordpress.com/2017/09/29/beckers-a-new-stoicism-ii-the-waythings-stand-part-1/ (accessed on 7 December 2018).

Pigliucci, Massimo. 2017b. How to Be a Stoic: Using Ancient Philosophy to Live a Modern Life. London: Hachette UK. Pigliucci, Massimo. 2017c. What Do I Disagree about with the Ancient Stoics? How to Be a Stoic. Available online: https: / howtobeastoic.wordpress.com/2017/12/26/what-do-i-disagree-about-with-the-ancientstoics / (accessed on 7 December 2018).

Pigliucci, Massimo. 2018. The Growing Pains of the Stoic Movement. How to Be a Stoic. Available online: https:/ /howtobeastoic.wordpress.com/2018/06/05/the-growing-pains-of-the-stoic-movement/ (accessed on 7 December 2018).

Protopapadakis, Evangelos. 2012. The Stoic Notion of Cosmic Sympathy in Contemporary Environmental Ethics. Antiquity, Modern World and Reception of Ancient Culture, The Serbian Society for Ancient Studies, Belgrade 2012: 290-305.

Raworth, Kate. 2017. Doughnut Economics: Seven Ways to Think Like a 21st-Century Economist. Vermont: Chelsea Green Publishing.

Robertson, Donald. 2017. Did Stoicism Condemn Slavery? Available online: https:/ /donaldrobertson.name/ 2017/11/05/did-stoicism-condemn-slavery/ (accessed on 1 February 2019).

Rockström, Johan, Will L. Steffen, Kevin Noone, Åsa Persson, F. Stuart Chapin III, Eric Lambin, Timothy M. Lenton, Marten Scheffer, Carl Folke, Hans Joachim Schellnhuber, and et al. 2009. Planetary boundaries: Exploring the safe operating space for humanity. Ecology and Society 14: 32. [CrossRef]

Rosling, Hans. 2010. The Magic Washing Machine. Available online: https:/ / www.ted.com/talks/hans_rosling_ and_the_magic_washing_machine (accessed on 7 December 2018).

Sadler, Greg. 2018. Is Stoicism a Religion?-Answers to Common Questions (Stoicism). Available online: https: / / www.youtube.com/watch?v=sBJOTSFrelA (accessed on 7 December 2018).

Sellars, John. 2006. Stoicism. Berkeley: University of California Press. 
Sellars, John. 2014. Which Stoicism? In Stoicism Today: Selected Writings. Edited by Patrick Ussher. Exeter: Stoicism Today Project.

Stankiewicz, Piotr. 2017. Interview with Piotr Stankiewicz. Modern Stoicism. Available online: https:// modernstoicism.com/interview-with-piotr-stankiewicz/ (accessed on 7 December 2018).

Steffen, Will, Paul J. Crutzen, and John R. McNeill. 2007. The Anthropocene: Are humans now overwhelming the great forces of nature. AMBIO: A Journal of the Human Environment 36: 614-21. [CrossRef]

Steffen, Will, Åsa Persson, Lisa Deutsch, Jan Zalasiewicz, Mark Williams, Katherine Richardson, Carole Crumley, Paul Crutzen, Carl Folke, Line Gordon, and et al. 2011. The Anthropocene: From global change to planetary stewardship. Ambio 40: 739. [CrossRef]

Steffen, Will, Katherine Richardson, Johan Rockström, Sarah E. Cornell, Ingo Fetzer, Elena M. Bennett, Reinette Biggs, Stephen R. Carpenter, Wim de Vries, Cynthia A. de Wit, and et al. 2015. Planetary boundaries: Guiding human development on a changing planet. Science 347: 1259855. [CrossRef]

Stephens, William O. 1994. Stoic Naturalism, Rationalism, and Ecology. Environmental Ethics 16: 275-86. [CrossRef] Stephens, William O. 2011. Marcus Aurelius: A Guide for the Perplexed. New York: Continuum.

Striker, Gisela. 1996. Following Nature. In Essays on Hellenistic Epistemology and Ethics. Cambridge: Cambridge University Press, pp. 221-80.

Swartz, Wilf, Enric Sala, Sean Tracey, Reg Watson, and Daniel Pauly. 2010. The spatial expansion and ecological footprint of fisheries (1950 to present). PLoS ONE 5: e15143. [CrossRef]

Taylor, Paul W. 2011. Respect for Nature: A Theory of Environmental Ethics, 25th ed. Princeton University Press: Princeton.

Thunberg, Greta. 2018. School strike for climate-Save the world by changing the rules. Available online: https: / / www.youtube.com/watch?v=EAmmUIEsN9A (accessed on 12 March 2019).

UN. 2015. Transforming Our World: The 2030 Agenda for Sustainable. Resolution Adopted by the General Assembly on 25 September 2015. New York: United Nations.

Whiting, Kai, and Leonidas Konstantakos. 2018. Stoicism and sustainability. Modern Stoicism. Available online: https:/ / modernstoicism.com/stoicism-and-sustainability-by-kai-whiting-and-leonidaskonstantakos / (accessed on 7 December 2018).

Whiting, Kai, Leonidas Konstantakos, Angeles Carrasco, and Luis Carmona. 2018a. Sustainable Development, Wellbeing and Material Consumption: A Stoic Perspective. Sustainability 10: 474. [CrossRef]

Whiting, Kai, Leonidas Konstantakos, Greg Misiaszek, Edward Simpson, and Luis Carmona. 2018b. Education for the Sustainable Global Citizen: What Can We Learn from Stoic Philosophy and Freirean Environmental Pedagogies? Education Sciences 8: 204. [CrossRef]

Whiting, Kai, Leonidas Konstantakos, Greg Sadler, and Christopher Gill. 2018c. Were Neanderthals Rational? A Stoic Approach. Humanities 7: 39. [CrossRef]

WWF. 2018. Living Planet Report-2018: Aiming Higher. Gland: World Wide Fund for Nature (WWF). 